\title{
Miejsce kolchicyny w leczeniu chorób układu sercowo-naczyniowego - metaanaliza 15 badań randomizowanych
}

\author{
Maciej Krzysztof Kluk \\ I Klinika Kardiologii i Elektroterapii Świętokrzyskiego Centrum Kardiologii w Kielcach
}

Kolchicyna jest lekiem stosowanym w terapii chorób o podłożu zapalnym, w tym chorób układu sercowo-naczyniowego, takich jak miażdżyca, zapalenie osierdzia, oraz niezapalnych, w tym migotania przedsionków związanego z zabiegami kardiochirurgicznymi. Mimo szerokiego spektrum wskazań w praktyce klinicznej lek znajduje zastosowanie przede wszystkim w leczeniu pericarditis. Verma i wsp. [1] podsumowali aktualną wiedzę na temat wskazań, potencjału leczniczego oraz bezpieczeństwa kolchicyny w chorobach kardiologicznych w formie metaanalizy badań randomizowanych.

Selekcja badań została wykonana na podstawie analizy zasobów baz MEDLINE, EMBASE oraz Cochrane łącznie z lat 1946-2014. Wybór dotyczył prospektywnych badań randomizowanych kontrolowanych placebo lub bez leczenia w porównaniu ze stosowaniem kolchicyny. Badania dotyczyły choroby niedokrwiennej serca, kardiomiopatii, niewydolności serca, zapalenia osierdzia i arytmii.

Punkt pierwszorzędowy zdefiniowano dwojako: w przypadku badań dotyczących choroby niedokrwiennej serca i niewydolności serca - jako złożony sercowo-naczyniowy punkt końcowy zależny od definicji przyjętej przez autorów poszczególnych prac, natomiast w przypadku badań obejmujących pacjentów z zapaleniem osierdzia lub po perikardiotomii - jako nawrót choroby lub konieczność ponownej operacji kardiochirurgicznej. Punkty drugorzędowe określono odpowiednio jako: zgon z każdej przyczyny, ostry zespół wieńcowy, zawał serca niezakończony zgonem, rewaskularyzację wieńcową oraz udar mózgu niezakończony zgonem lub jako wystąpienie arytmii (w przypadku zapalenie osierdzia, zespołu postkardiotomijnego lub po procedurze ablacji prądem o częstotliwości radiowej).

Ostatecznie do metaanalizy włączono 15 badań randomizowanych obejmujących łącznie 3431 pacjentów, przy czym 5 badań dotyczyło choroby niedokrwiennej serca lub stabilnej niewydolności serca, kolejne 5 - różnych postaci zapalenia osierdzia, w tym nawrotowych, 4 - zespołu objawów po perikardiotomii, a 1 badanie - wyników po zabiegu ablacji podłoża migotania przedsionków.

W większości badań, tj. 13, stosowano dawkę kolchicyny równą $1 \mathrm{mg} /$ dobę; w blisko połowie przypadków stosowano zmniejszenie dawki do $0,5 \mathrm{mg} /$ dobę w sytuacji nietolerancji leku lub masy ciała poniżej $70 \mathrm{~kg}$. Mediana okresu leczenia wynosiła 3 miesiące, zaś mediana okresu obserwacji - 15 miesięcy (zakres 7 dni do 3 lat).

W przypadku badań nieobejmujących zapalenia osierdzia pacjenci byli młodsi oraz rzadziej płci męskiej niż w badaniach dotyczących pericarditis (w przypadku płci męskiej odpowiednio 35-60\% v. 65-89\%). Pacjenci z zapaleniem osierdzia charakteryzowali się obecnością czynników ryzyka miażdżycy, takich jak nadciśnienie tętnicze, cukrzyca, dyslipidemia i palenie tytoniu. Z metaanalizy wykluczono chorych z zastoinową niewydolnością serca oraz ciężkim upośledzeniem funkcji nerek.

Dwanaście wyselekcjonowanych badań kontrolowano placebo i przeprowadzono metodą ślepej próby. Trzynaście badań miało charakter analizy stosowania kolchicyny z intencją wyleczenia; również w 13 przypadkach nie przerywano leczenia nawet po wcześniejszym uzyskaniu korzyści z terapii.

W badaniach obejmujących pacjentów z chorobą niedokrwienną serca i/lub niewydolnością serca (1301 osób) wykazano istotną redukcję w zakresie pierwszorzędowego punktu końcowego w przypadku stosowania kolchicyny (ryzyko względne [RR, relative risk] =0,44; 95-proc. przedział ufności [Cl, confidence interval]: 0,28-0,69; $\mathrm{p}=$ $=0,0004$ ) oraz trend ku zmniejszonej śmiertelności ogólnej $(\mathrm{RR}=0,50 ; 95 \% \mathrm{Cl}: 0,23-1,08 ; \mathrm{p}=0,08) . \mathrm{W}$ badaniach

Adres do korespondencji: lek. Maciej Krzysztof Kluk, I Klinika Kardiologii i Elektroterapii, Świętokrzyskie Centrum Kardiologii, ul. Grunwaldzka 45, 25-736 Kielce, tel. 4136713 91/13 88, faks 41367 13 96, e-mail: maciej.kluk@gmail.com 
obejmujących pacjentów z zapaleniem osierdzia wykazano zmniejszenie liczby nawrotów pericarditis lub zespołu po kardiotomii (punkt pierwszorzędowy; $n=1635$; $R R=0,50$; 95\% Cl: 0,41-0,60; $p<0,0001)$ oraz redukcję liczby incydentów migotania przedsionków po perikardiotomii lub ablacji podłoża arytmii $(\mathrm{n}=1118$; $\mathrm{RR}=0,65 ; 95 \% \mathrm{Cl}$ : 0,51-0,82; $p=0,0003)$.

Analiza działań niepożądanych dowiodła, że najczęściej występowały biegunki oraz inne zaburzenia czynności przewodu pokarmowego (2-krotny wzrost ryzyka; RR = 2,06; $95 \% \mathrm{Cl}: 1,56-2,72 ; \mathrm{p}<0,0001)$. Zaburzenia te natomiast nie występowały istotnie częściej u pacjentów z zapaleniem osierdzia, u których dokonano zmniejszenia dawki leku (nietolerancja, masa ciała $<70 \mathrm{~kg}$ ), przy czym osoby z tej grupy były istotnie młodsze.

Istotnie częściej przerywano leczenie kolchicyną w stosunku do czynnika kontrolnego - zarówno z wszystkich przyczyn (RR = 1,85; 95\% Cl: 1,33-2,59; $p=0,0003$ ), jak i z powodu działań niepożądanych (RR $=4,34$; 95\% Cl: 1,70-11,07; $p=0,002)$. Zależność ta nie zależała od wskazań do stosowania kolchicyny.

Do głównych ograniczeń pracy autorzy zaliczyli niejednorodność pierwszorzędowego punktu końcowego w przypadku badań obejmujących pacjentów z chorobą niedokrwienną serca i niewydolnością serca, jak również niską częstość raportowanych działań niepożądanych innych niż pochodzenia gastroenteralnego [1].

Kolchicyna wpływa na ograniczenie występowania niepożądanych zdarzeń sercowo-naczyniowych, jak również obniża ryzyko nawrotu zapalenia osierdzia, wystąpienia zespołu po kardiotomii oraz migotania przedsionków po zabiegach kardiochirurgicznych lub ablacji podłoża migotania przedsionków. Postulowanym głównym mechanizmem działania pośredniczącym w tych korzystnych efektach działania leku jest mechanizm przeciwzapalny [1].

Wpływ endogennej aktywności agregacyjnej płytek krwi na ryzyko powikłań krwotocznych u pacjentów z migotaniem przedsionków leczonych przeciwkrzepliwie - subanaliza badania SAFETY

Standardem terapii pacjentów z migotaniem przedsionków jest stosowanie przewlekłej terapii przeciwkrzepliwej (antagoniści witaminy $\mathrm{K}$ [VKA, vitamin $\mathrm{K}$ antagonists] lub nowe doustne antykoagulanty niebędące antagonistami witaminy K [NOAC, non-vitamin K antagonist oral anticoagulants]) w celu zapobiegania powikłaniom zakrzepowo-zatorowym. Jednocześnie leki przeciwkrzepliwe podwyższają ryzyko krwawień, których ryzyko jest oceniane w skali HAS-BLED (Hypertension, Abnormal renal and liver function, Stroke, Bleeding, Labile INRs, Elderly, Drugs or alcohol). Czynnikami dodatkowymi wpływającymi na zwiększenie ryzyka powikłań krwotocznych są stosowanie jednoczasowo leków przeciwpłytkowych i upośledzona funkcja nerek. Autorzy prezentowanej pracy postanowili sprawdzić, czy endogenna aktywność agregacyjna płytek krwi (niezwiązana z leczeniem przeciwpłytkowym) może wpływać na ryzyko krwawień u pacjentów przyjmujących doustne antykoagulanty.

Badanie miało charakter prospektywny i jednoośrodkowy, stanowiąc subanalizę badania SAFETY (Standard vs Atrial Fibrillation speciFic managemenT studY), w którym oceniano skuteczność metod niefarmakologicznej kontroli migotania przedsionków u pacjentów hospitalizowanych z powodu arytmii. Kryterium włączenia do subanalizy stanowiło przewlekłe migotanie przedsionków będące przyczyną hospitalizacji. Kryteria wykluczenia były tożsame z ogólnymi kryteriami przyjętymi w badaniu SAFETY i były to: wiek poniżej 45. roku życia, choroba zastawkowa, planowana ablacja podłoża migotania przedsionków, obecna niewydolność serca w III-IV klasie według New York Heart Association (NYHA) z frakcją wyrzutową lewej komory mniejszą niż 45\%, migotanie przedsionków związane z nadużywaniem alkoholu oraz choroba wymagająca opieki paliatywnej. Do subanalizy nie włączano ponadto pacjentów przyjmujących leki z grupy antagonistów receptora $\mathrm{P}_{2} \mathrm{Y}_{12}$, które mogłyby zaburzać ocenę aktywności agregacyjnej płytek krwi.

Do badania włączono 83 pacjentów poddanych kompleksowej ocenie klinicznej, z uwzględnieniem oceny zapisu elektrokardiograficznego, obrazu echokardiograficznego (ocena funkcji skurczowej lewej komory - frakcja wyrzutowa lewej komory obliczona metodą Simpsona), stratyfikacji ryzyka w skalach $\mathrm{CHA}_{2} \mathrm{DS}_{2}$ VASc (Congestive heart failure) /LV dysfunction, Hypertension, Age, Diabetes mellitus, Stroke, Vascular disease, Age, Sex category) i HAS-BLED. Okres obserwacji wynosił 12 miesięcy - w tym czasie nie obserwowano wystąpienia udaru mózgu, natomiast u 9 pacjentów doszło do istotnego krwawienia. Charakterystykę kliniczną pacjentów przedstawiono w tabeli 1.

W celu oceny aktywności agregacyjnej płytek krwi zastosowano porównawczo różne metody: agregometrię impedancyjną, ocenę stężenia substancji hamujących agreacje płytek - asymetrycznej i symetrycznej dimetylargininy - ocenę stężenia trombospondyny-1 (TSP-1) oraz ocenę aktywności białka reagującego z tioredoksyną (Txnip, thioredoxin interacting protein). Agregację płytek krwi stymulowano, podając adenozynodifosforan (ADP, adenosine diphosphate).

Aktywność agregacyjna płytek krwi $(\Omega)$ była większa u kobiet niż u mężczyzn $(9,9$ v. 7,2; p < 0,05). Wartość $\Omega$ nie zależała od stosowania kwasu acetylosalicylowego w terapii, wykazywała natomiast zależność odwrotnie proporcjonalną do punktacji w skali HAS-BLED ( $r=-0,220$; $\mathrm{p}<0,05)$, przy braku zależności od punktacji w skali $\mathrm{CHA}_{2} \mathrm{DS}_{2}$ VASc.

W analizie jednoczynnikowej dowiedziono, że zarówno stężenie symetrycznej, jak i asymetrycznej dimetylargininy 
Tabela 1. Charakterystyka kliniczna pacjentów (źródło [2])

$\begin{array}{lc}\text { Cecha } & \text { Wartość } \\ \text { Płeć męska, n (\%) } & 43(51,8) \\ \text { Wiek (mediana, kwartyle) } & 73(67-81) \\ \text { Frakcja wyrzutowa (mediana, kwartyle) (\%) } & 59(52-65) \\ \text { Częstość rytmu serca przy przyjęciu } & 81(66-112) \\ \text { (uderzenia/min) } & \\ \text { Wskaźnik przesączania kłębuszkowego } & 65,69 \pm 2,47 \\ \text { [ml/min/1,73 m²] } & \\ \text { Punktacja w skali CHA }{ }_{2} \text { DS }{ }_{2} \text { VASc } & 3(2-4) \\ \text { Punktacja w skali HAS-BLED } & 2(2-3) \\ \text { Niewydolność serca (n, \%) } & 6(7,2) \\ \text { Nadciśnienie tętnicze (n, \%) } & 58(69,9) \\ \text { Cukrzyca (n, \%) } & 22(26,5) \\ \text { Udar mózgu/TIA (n, \%) } & 13(15,7) \\ \text { Kwas acetylosalicylowy (n, \%) } & 27(32,5) \\ \text { Warfaryna (n, \%) } & 49(59,0) \\ \text { Leki antyarytmiczne (n, \%) } & 22(26,5) \\ \text { Beta-adrenolityki (n, \%) } & 48(57,8) \\ \text { Inhibitory konwertazy angiotensyny (n, \%) } & 26(31,3) \\ \text { Antagoniści receptora dla angiotensyny II } & 23(27,7) \\ \text { (n, \%) } & \\ \text { Statyny (n, \%) } & 44(53,0)\end{array}$

$\mathrm{CHA}_{2} \mathrm{DS}_{2} \mathrm{VASc}$ - Congestive heart failure/LV dysfunction, Hypertension, Age, Diabetes mellitus, Stroke, Vascular disease, Age, Sex category; HAS-BLED - Hypertension, Abnormal renal and liver function, Stroke, Bleeding, Labile INRs, Elderly, Drugs or alcohol; TIA (transient ischaemic attack) - przemijający napad niedokrwienny

koreluje ze zmniejszoną $\Omega$ (odpowiednio: $r=-0,308$; $p<0,01$ i $r=-226 ; p<0,05)$, natomiast wskaźnik

\section{Piśmiennictwo}

1. Verma S., Eikelboom J.W., Al-Omran M. i wsp. Colchicine in cardiac disease: a systematic review and meta-analysis of randomized controlled trials. BMC Cardiovascular Dis. 2015; 15: 96. przesączania kłębuszkowego $(r=0,250 ; p<0,05)$ oraz stężenia TSP-1 $(r=0,262 ; p<0,01)$ i Txnip $(r=0,298$; $p<0,01$ ) korelują ze zwiększoną $\Omega$. W analizie wieloczynnikowej czynnikiem istotnie korelującym ze zmniejszoną aktywnością agregacyjną płytek krwi jest stężenie symetrycznej dimetylargininy $(\beta=-0,318 ; p<0,01)$, natomiast stężenia TSP-1 i Txnip - ze zwiększoną $\Omega$ (odpowiednio: $\beta=0,261 ; p<0,05$ i $\beta=0,249 ; p<0,05)$. Ponadto im niższy jest wskaźnik przesączania kłębuszkowego, tym jest wyższe stężenie symetrycznej dimetylargininy $(r=-0,780$; $p<0,001$ ), co pośrednio może powodować zmniejszenie aktywności agregacyjnej płytek krwi, a więc zwiększać ryzyko krwawienia. Wskazano również, że stężenie symetrycznej dimetylargininy korelowało ze zwiększeniem punktacji w skali HAS-BLED ( $r=0,478 ; p<0,001)$, natomiast im był niższy wskaźnik przesączania kłębuszkowego, tym było wyższe ryzyko krwawienia w skali HAS-BLED ( $r=0,573$; $p<0,001)$.

Głównym ograniczeniem pracy wydaje się niedoszacowanie częstości powikłań krwotocznych ze względu na małą liczebność grupy [2].

W grupie pacjentów z migotaniem przedsionków poddanych przewlekłej terapii lekami przeciwkrzepliwymi fizjologicznie upośledzona agregacja płytek krwi wpływa na zwiększenie ryzyka powikłań krwotocznych. Jedną z przyczyn obniżonej aktywności agregacyjnej płytek krwi może być umiarkowanie i ciężko upośledzona funkcja nerek [2].

\section{Konflikt interesów}

Autor nie zgłasza konfliktu interesów.

2. Procter N.E.K., Ball J., Heresztyn T. i wsp. Subtle renal dysfunction and bleeding risk in atrial fibrillation: symmetric dimethylarginine predicts HAS-BLED score. Am. J. Cardiovasc. Dis. 2015; 5: 101-109. 